\title{
El moviment per l'okupació i el moviment per l'habitatge: semblances, diferències i confluències en temps de crisi
}

\author{
Squatting Movement and Housing Movement: Similarities, \\ Differences and Convergences in Times of Crisis
}

\author{
ROBERT GONZÁLEZ GARCÍA
}

Instituto de Ciencias Sociales y Humanidades. Universidad Autónoma del Estado de Hidalgo (México)

Artículo recibido: 6 junio 2014

Solicitud de revisión: 8 febrero 2015

Artículo aceptado: 21 junio 2015

\section{Resum}

Les pràctiques d'okupació que sorgeixen a mitjans dels 80 al nostre país són considerades un moviment social per múltiples autors (Calle, 2004; Pruijt, 2004; Martínez, 2002). L'any 2006 apareix arreu de l'Estat un nou moviment social diferenciat, el moviment per l'habitatge. Aquest moviment organitzà joves d'arreu de l'Estat espanyol i, els anys posteriors, consolidà centenars de plataformes d'afectats per les hipoteques de totes les edats. Les seves propostes $\mathrm{i}$ demandes han estat un full de ruta en l'aterratge pràctic del moviment del 15-M. L'objectiu d'aquest article és comparar aquests dos moviments urbans que es poden entendre també com a pràctiques emancipadores i noves formes de participació de la societat civil.

Paraules clau: joventut, okupació, habitatge, crisi, moviments socials

\section{Abstract}

The practical of squatting that arrived to our country in the 80's is considered a social movement by multiple authors (Calle, 2004; Pruijt, 2004; Martínez, 2002). The year 2006 appears a new and differentiated social movement, the housing movement. This movement organized young people of all over the country, and therefore consolidated hundreds of platforms of affected by the mortgages of different ages. Their proposals and demands have been a rate routing coming from the 15-M movement. The aim of this article is to compare these two urban movements that could be also understood as emancipation practices and new shapes of participation of the civil society.

Keywords: youth, squatting, housing, crisis, social movements 


\section{INTRODUCCIÓ}

L'objectiu d'aquest article és comparar dos moviments socials contemporanis que han protagonitzat lluites socials importants a l'Estat espanyol entorn de temàtiques com l'accés a l'habitatge i a espais de sociabilitat comunitària. El moviment per l'okupació i el moviment per l'habitatge presenten similituds i sovint confluències, però són dos moviments diferents, tant en el seu procés històric com en les seves formes organitzatives, objectius i lideratges.

En el primer apartat analitzarem les pràctiques d'okupació que s'originaren en el context europeu a la dècada dels setanta i s'instal-laren a Catalunya i Espanya ${ }^{1}$ a la dècada dels vuitanta. Veurem com l'okupació ha esdevingut un moviment social amb tots els ets $i$ uts $i$ farem un repàs als ja 30 anys d'història de les okupacions al nostre país.

Per altra banda, l'any 2006 apareix el moviment per l'habitatge. Aquest moviment organitzà joves d'arreu de l'Estat $i$, els anys posteriors, va consolidar centenars de col-lectius locals per l'habitatge. En els darrers temps han guanyat protagonisme les Plataformes d'Afectats per les Hipoteques (les PAH). Les seves propostes i demandes han estat un full de ruta en l'aterratge pràctic del moviment 15-M, amb propostes com la dació en pagament, desnonaments zero o la desaparició del parc de pisos buits. En el segon apartat explicarem la gènesi del moviment per l'habitatge i el sorgiment de les PAH.

En el tercer apartat compararem aquests dos moviments urbans, situantlos en un context més ampli de lluites contra la globalització neoliberal. S'analitzaran les semblances i diferències entre ambdós moviments en termes d'identitat, relació amb les institucions, estratègies, objectius, organització, concepció de l'okupació i composició social dels seus activistes.

A les conclusions reflexionarem sobre les semblances, diferències i confluències entre okupació i moviment per l'habitatge, essent conscients que caldran nous estudis empírics per validar o falsar les hipòtesis comparatives que es plantegen.

1 L'article analitza els casos de Catalunya, Madrid i el País Basc, ja que aquests han estat estudiats per l'autor en la seva tesi doctoral (González, 2011) i en posteriors recerques. En concret, l'article s'emmarca dins la recerca "El movimiento de okupación de viviendas y centros sociales en España y en Europa: contextos, ciclos, identidades e institucionalización", que es portà a terme entre gener de 2012 i desembre de 2014. 


\section{EL MOVIMENT PER L'OKUPACIÓ A CATALUNYA I A L'ESTAT ESPANYOL: CARACTERÍSTIQUES I RESUM HISTÒRIC}

\subsection{Les pràctiques d'okupació com a moviment social}

L'okupació d'immobles abandonats per a construir centres socials o habitatges s'adapta a les idees fonamentals per a definir un moviment social present a la literatura acadèmica: conflicte, desafiament, canvi i acció collectiva (Pastor, 2002). A més a més, les pràctiques d'okupació han transcendit el camp de la protesta, per acabar desembocant en una sèrie de discursos, repertoris d'acció i formes organitzatives, que les doten d'una identitat cultural compartida fortament emparentada amb el sorgiment dels nous moviments socials a Europa (feminisme, pacifisme, ecologisme, autonomia obrera, etc.) (Calle, 2004).

Ara bé, què és okupar? Pel sociòleg holandès Hans Pruijt okupar és viure en (o usar d'una altra manera) immobles sense el consentiment del seu propietari (Pruijt, 2004). Podríem afegir -tal i com apunta Martínez- que es tracta d'un moviment que se centra en l'accés directe a un bé urbà escàs (l'habitatge i els espais de sociabilitat) i la seva legítima defensa (Martínez, 2004). De tota manera, existeixen i conviuen diverses pràctiques d'okupació. Per sentit comú, podríem distingir aquelles que es dediquen a satisfer una necessitat d'habitatge de les que es converteixen en Centres Socials Okupats (Cso) on realitzar tot tipus d'activitats contraculturals en un espai públic no estatal -fora de les lògiques burocratitzades (de l'Estat) o mercantilitzades (del sector privat).

Hans Pruijt distingeix fins a cinc configuracions ${ }^{2}$ de l'okupació (2004: 37-60), que ens dóna idea de l'extraordinària diversitat del fenomen: a) l'okupació basada en la pobresa que implica la participació de persones sense recursos econòmics que realitzen okupacions a causa d'una situació extrema de privació d'habitatge; b) l'okupació com a estratègia alternativa d'habitatge, que inclou una varietat de situacions personals i tipus diferents d'okupes; c) l'okupació emprenedora, que permet fer activitats econòmiques i laborals autogestionades en els centres socials; $d$ ) l'okupació conservacionista, que esdevé una tàctica usada en la preservació del paisatge rural

2 Les configuracions són una mena de models o combinacions de característiques que juntes encaixen bé (Mintzberg, 1983, citat a Pruijt, 2004:37). En el cas de l'okupació, les configuracions difereixen en les característiques de les persones implicades, el tipus d'immobles, els marcs cognitius, les seves demandes i els patrons d'organització i mobilització que desenvolupen. 
i urbà, i e) l'okupació política, aquella en la qual s'identifiquen els activistes antisistema (ja siguin revolucionaris o autònoms).

El context social que facilita l'aparició d'okupacions és el producte dels processos de desestructuració de les xarxes socials que genera la globalització neoliberal, en forma d'una precarietat vital i d'uns riscos d'exclusió social creixents entre la població. Les dificultats per accedir a un habitatge i la precarietat laboral s'han generalitzat en les darreres dècades, acarnissant-se especialment en el sector juvenil i convivint amb paradoxes com l'existència d'una enorme quantitat d'habitatges buits fruit de l'especulació immobiliària.

D'altra banda, l'oferta de cultura i oci del món privat es torna cada cop més alienant, amb la profusió de grans superfícies, macrodiscoteques i multicines, que fomenten el consum a discreció. A més de les "prestacions" logístiques, els cso compleixen una tasca de rearticulació de les xarxes socials locals, destrossades pel procés de globalització neoliberal. Les xarxes informals que s'estableixen en les okupacions i els desallotjaments són percebudes pels i les okupes com una recuperació positiva de sobirania sociovital (Calle, 2004).

En paraules de Martínez, en okupar, no només se sostrauen immobles abandonats de les lògiques especulatives-capitalistes, sinó que es genera el principal recurs per portar a terme l'autogestió col-lectiva i per reprendre les relacions socials i les formes de vida que reptin directament les imposicions del mercat i de la legalitat i les institucions al seu servei (Martínez, 2010). Quant a les característiques físiques del territori urbà on es produeixen les okupacions, Martínez apunta que, com a tendència general, les okupacions a l'Estat espanyol se solen localitzar en tres llocs: 1) als centres històrics i urbans (Lavapiés i Tetuán a Madrid; Raval, Ciutat Vella, Gràcia o Sants a Barcelona); 2) en àrees de reconversió industrial i fâbriques o instal-lacions deslocalitzades (Baix Llobregat i Vallès Occidental a Barcelona o el marge esquerre a Bilbao), i 3) en zones de renovació urbana amb "grans projectes" terciaris o residencials (Poble Nou a Barcelona o El Cabanyal a València). A aquestes tres ubicacions preferencials, cal afegir l'okupació en zones periurbanes (com Collserola a Barcelona o Leioa a Biscaia), propietats abandonades per l'Estat (la Kasa de la Muntanya a Gràcia) o l'Església (com l'Escola de la Prosperitat a Madrid o el Gaztetxe de Santutxu a Bilbao) i edificis d'habitatges sense llicències (El Puntal i Esperanza 8, al barri de Lavapiés de Madrid) (Martínez, 2004: 84).

En definitiva, l'okupació a l'Estat espanyol tindria una condició ambivalent. És a dir, d'una banda, l'okupació es pot entendre com una arma de 
combat per a portar a terme un projecte transformador. Un altra visió correspondria a l'okupació com a mitjà per a engegar projectes d'experimentació personal i col-lectiva, seguint pautes de comportament alternatives, sota una lògica d'insubmissió quotidiana. Es considera, doncs, que les okupacions són, d'una banda, fi en si mateixes, espais recuperats a un sistema de propietat basat en l'especulació i en el predomini del valor de canvi sobre el valor d'ús; però, al mateix temps, són un mitjà per a portar a terme una lluita global contra el sistema.

Podem dividir la història del moviment per l'okupació en tres etapes. Per decidir on comencen $i$ on acaben les etapes partim de les teories de cicles (Tarrow, 1997) i dels canvis en les estructures d'oportunitat política ${ }^{3}$ del moviment per l'okupació. En la darrera etapa coincidirà i en alguns casos confluirà (i estarà en la gènesi) amb el moviment per l'habitatge.

\subsection{Naixement i consolidació (1984-1995)}

A Catalunya la primera okupació es produí al barri de Gràcia de Barcelona el desembre de 1984. D'altres destacades d'aquesta primera etapa foren l'Ateneu de Cornellà (que durà de 1986 a 2003) i la Kasa de la Muntanya, també a Gràcia i okupada des de 1989 (continua activa). A Madrid, una incipient Assemblea d'Okupes va protagonitzar la històrica okupació de Minuesa el 1987. Pel que fa a Euskadi, el naixement del moviment per l'okupació es produí al voltant dels moviments juvenils dels anys vuitanta. Van començar a aparèixer Gaztetxes (cases dels joves) per tot Euskal Herria. Les més emblemàtiques foren les okupacions de la Borsa de Bilbao, la del Gaztetxe de Gazteiz (Vitòria), així com l'Euskal Jai de Pamplona-Iruñea.

A partir de 1992 es va produir una obertura del moviment, derivada de la incidència del moviment estudiantil, antimilitarista i feminista, entre d'altres (González, Blas i Pelàez, 2002; Herreros, 2004). L'any 1992 semblava articularse la primera resposta al context de reestructuració capitalista de les grans ciutats, expressada a través de tres esdeveniments: $a$ ) els Jocs Olímpics de Barcelona, $b$ ) l'Exposició Universal de Sevilla, i c) la Capitalitat Cultural de Madrid (Martínez, 2004).

3 Sobre el concepte d'estructura d'oportunitats polítiques, veure Kitschelt (1996) i Mc Adam (1998). 


\subsection{Etapa daurada (1996-2000)}

La criminalització de l'okupació en el nou Codi Penal (1996) va marcar l'inici d'una expansió de les okupacions. L'estratègia de repressió del moviment per part de les institucions suposà paradoxalment la seva revitalització. D'altra banda cal sumar el salt a l'arena mediàtica del moviment amb els desallotjaments del Princesa a Barcelona o de la Guindalera a Madrid. A Catalunya les okupacions passaren de 40 a 150 en dos anys. A ambdós territoris el moviment okupa esdevingué el referent dels moviments socials juvenils radicals i protagonitzà manifestacions, resistències a desallotjaments i un gran nombre d'okupacions. El cso Can Vies, al barri de Sants de Barcelona, okupat el 1997, simbolitza perfectament aquest període de puixança del moviment. ${ }^{4}$

Cap als anys 1999 i 2000, el moviment començava a reflectir certs símptomes de canvi. D'una banda, els espais de coordinació i organització interna es van anar perdent per a afirmar les identitats particulars de cada casa okupada. D'altra banda, l'estratègia repressiva de l'Estat va provocar una conjuntura de conflicte permanent amb la policia que va arribar al seu punt àlgid el 2001 amb les detencions d'algunes persones relacionades amb la protesta okupa, acusades de pertànyer a ETA a Barcelona o als GRAPO a Madrid (Asens, 2004).

\subsection{Perspectives del moviment per l'okupació contemporani (2001-2015)}

Són diverses les aportacions que apunten cap a l'inici d'un nou cicle en el moviment de les okupacions a partir de l'any 2001 (Martínez, 2007; Herreros, 2004; Miró, 2001). Els canvis operats en les estructures d'oportunitat política del moviment van estar provocats, entre d'altres elements, per l'inici el 1999 (Seattle) d'un nou cicle de protesta a escala internacional, que es manifestà a l'Estat espanyol en la primera dècada del 2000.

En aquest període el moviment s'hibridà amb d'altres. En primer lloc, es produïren confluències amb el moviment global, tant en les campanyes puntuals com en alguns centres socials okupats com Can Masdeu a Barcelona o el Laboratorio a Madrid. En segon lloc, la confluència amb sectors del moviment veïnal en el que s'anomenà "la crítica pràctica a l'urbanisme capitalista"

4 El seu desallotjament el 26 de maig de 2014 desfermà una onada de protestes arreu de Catalunya que mostren l'arrelament social i polític d'un centre social per on passaren fins a tres generacions diferents de joves okupes. La seva pervivència li permeté participar i relacionar-se fortament amb diversos cicles de mobilització, com el de les lluites contra la globalització neoliberal (2000-2004) o el del 15-M de 2011. 
(Miró, 2001:3). I tercer: el sorgiment els anys 2004 i 2005 de nous espais de lluita sobre la temàtica capital-treball, a l'entorn de les deslocalitzacions d'empreses i la precarietat laboral creixent.

En aquesta tercera etapa la pràctica de l'okupació s'estén i desborda el camp clàssic de l'okupació. Així, des d'altres subjectivitats i identitats diferents a l'okupa, es recorre a l'okupació com una eina potent de lluita. Okupacions com la de la Rimaia -protagonitzada pel moviment estudiantil contra Bolonya-, el cso Barrilonia -per part del moviment d'immigrants- o les okupacions d'horts urbans - per part de coalicions heterodoxes d'activistes de la permacultura i l'agroecología- en són exemples a Barcelona.Al mateix temps, a Madrid, l'aparició de noves subjectivitats okupes com el Patio Maravillas o La Eskalera Karakola, confirmen aquesta tendència. En el cas català, a més, cal afegir l'aposta de l'independentisme revolucionari per l'okupació, que es tradueix -durant la dècada dels 2000- en les nombroses okupacions de les assemblees de joves de l'esquerra independentista arreu del territori. Finalment, com veurem en l'apartat següent, diferents nuclis del moviment per l'habitatge (especialment de les $\mathrm{PAH}$ ), del 15-M, del cooperativisme i del propi moviment per l'okupació, okupen edificis d'habitatges per a persones afectades per l'onada massiva de desnonaments entre els anys 2011 i 2013. De fet, alguns autors (Martínez i García, 2013) apunten cap a l'inici d'una quarta etapa en la història del moviment l'any 2011.

\section{EL MOVIMENT PER L'HABITATGE. PINZELLADES SOBRE UNA HISTÒRIA RECENT}

Aquest apartat analitza els contextos i l'evolució del moviment per l'habitatge a l'Estat espanyol, centrant-se en l'observació directa, l'anàlisi dels documents generats pel propi moviment i entrevistes semiestructurades i en profunditat a diferents activistes de les Plataformes d'Afectats per la Hipoteca (РAH) realitzades entre novembre de 2013 i abril de 2014 a Catalunya.

\subsection{Contextos socials d'aparició d'un nou moviment}

La problemàtica concreta de l'habitatge al nostre país i el context actual de crisi econòmica són els principals contextos de sorgiment del moviment per l'habitatge. La crisi ha produit un lleu retard en la ja de per sí elevada 
edat d'emancipació dels joves catalans i espanyols. L'elevat preu del lloguer i de la compra d'habitatge és un dels motius d'aquest retard, que situa en uns 29 anys l'edat mitjana d'emancipació dels joves espanyols, enfront dels 23 anys de Finlàndia, per exemple. De fet, el percentatge de joves emancipats de 16 a 34 anys ha passat del 44,8 \% el 2007 al 44,1\% el 2011 (Moreno et alt., 2012: 180).

El preu mig de la compra i el lloguer han estat durant molts anys elevadíssims i ho continuen estant en l'actualitat malgrat que els darrers quatre anys estan experimentant baixades notables ${ }^{5}$.A Barcelona, per exemple, l'any 2005 l'esforç econòmic per a comprar un pis era de 1475 euros al mes i per llogar-lo de 735, la qual cosa suposava el 45,1\% dels ingressos d'una llar mitjana, molt per sobre del màxim del $30 \%$ recomanat per Nacions Unides (Trilla i López, 2007: 752).

L'enorme parc de pisos buits, fruit de l'especulació immobiliària, no ha fet més que créixer. Així, si al cens de l'ine de 2001 se'n comptabilitzaven uns 3,1 milions, el darrer cens de 2011 podria situar la xifra en 6 milions. ${ }^{6}$ Aquestes xifres es deuen també al model de creixement espanyol, basat fortament en la construcció, que l'any 2007 arribà a representar el 9,3 \% del PIB (més del doble que als Estats Units) (Romero, 2010: 18).

La temporalitat dels contractes laborals i les taxes d'atur altíssimes (de més del $25 \%$ i de més del $40 \%$ en el cas dels joves) formen part també d'aquest context que dificulta l'accés a l'habitatge a milions de persones. La conversió de l'habitatge en una pura mercaderia i en objecte de l'especulació ha estat fonamental en el model de creixement econòmic espanyol, creant greus desequilibris socials, humans i mediambientals.

Paral-lelament, a la ciutat de Barcelona s'executaven 30 desnonaments diaris l'any 2009, segons la Plataforma per un Habitatge Digne (El Debat.cat, 11 de febrer de 2009).

En el total de l'Estat espanyol 500 persones perdien la casa diàriament des de 2008, segons dades de les PAH (El País, 3 de juny de 2010). La crisi de les hipoteques ha disparat els desnonaments -uns 400.00 des que va començar la crisi el 2008- l'endeutament de per vida de milers de persones i l'augment del nombre de suïcidis amb aquest motiu com a causa directa (Colau i Ale-

5 Aquest fet va posar les famílies en una espiral de deute molt important, que no té en compte que amb els preus actuals l'esforç econòmic s'ha reduït al 30 \% i una mitjana de dos salaris anuals a Catalunya (http://www.niu.cat/ca/noticies-niu-cat/minim-historic-lesforc-familiar-per-adquiriri-habitatge).

6 Vegeu: http://www.elmundo.es/elmundo/2011/08/22/suvivienda/1314001038.html, http://economia. elpais.com/economia/2012/01/05/actualidad/1325752378_850215.html i http://www.eleconomista.es/vivienda/noticias/3653831/01/12/En-Espana-podria-haber-hasta-seis-millones-de-pisos-vacios. html. Consultades el 31 de març de 2013. 
many, 2012:32). Al mateix temps, la insuficiència de les polítiques d'habitatge que prioritzen els interessos de propietaris i mercat sobre el dret a l'habitatge (tot i que aquest està recollit fins i tot a la cE, art. 47) s'han fet evidents en els darrers anys.

La desconfiança en els partits polítics, l'increment de la desafecció, la corrupció, les promeses incomplertes i, -en definitiva- la configuració de l'anomenada democràcia sense alternativa pròpia dels països perifèrics de la Unió Europea en l'actual context de crisi i polítiques d'austeritat, completen el context de sorgiment del moviment per l'habitatge que a través d'organitzacions de caire assembleari i d'acció directa com la PAH canalitza les demandes i les necessitats de milers de persones afectades i solidàries (Alonso, 2014; Colau i Alemany, 2013).

\subsection{Breu història: de "V de Vivienda" a la PAH}

Cap moviment social sorgeix un dia concret, però en el cas d'aquesta nova onada del moviment per l'habitatge, sí que hi podríem posar una data fundacional o un mite originari.Aquest moviment va experimentar un sorgiment espontani i sorpresa arran d'una convocatòria anònima per la xarxa el 14 de maig de 2006. La convocatòria tenia però un bon referent polític, les lluites juvenils a França contra el Primer Contracte. De fet, de forma irònica comparava aquestes amb les mobilitzacions en favor del "botellot" que per aquells dies es produïen en diverses ciutats d'Espanya. La convocatòria d' "assegudes" a diverses places de les principals ciutats aquell dia de maig de 2006 fou tot un èxit i desembocà en manifestacions i assemblees espontànies. En totes elles es podia apreciar la presència d'un petit nucli activista, provinent del moviment okupa, el moviment veïnal i l'esquerra anticapitalista, rodejat d'un nombrós grup de gent "nova", afectada directament pel problema de l'habitatge. Els activistes aportaren eines per potenciar les mobilitzacions (el saber fer) però els nous contingents "militants" aportaren frescor i això es feia evident en les consignes i les formes de mobilització. Per exemple una de les consignes o lemes més famosos fou: No tendrás una casa en la puta vida, mostra de la sensació d'impotència i de ràbia d'àmplies masses populars despolititzades fins aleshores. Aquests elements es reproduiran amplificats en el moviment dels indignats el 15 de maig de 2011.

Les vinculacions amb el moviment okupa en aquest primer període es fan evidents a través de l'Espai Social Magdalenes a Barcelona o el Patio Maravillas a Madrid.Tots dos centres socials okupats coincideixen en presentar-se 
com a partidaris de la negociació amb les administracions i en generar -per aquest motiu- gran controvèrsia a l'interior d'un moviment okupa, posicionat majoritàriament en contra.

L'Espai Social Magdalenes es definia com:

Un projecte ubicat a Ciutat Vella que té per objectiu fomentar l'autogestió, així com promoure i allotjar iniciatives que garanteixin l'exercici i la defensa d'aquells drets que no es troben actualment garantits en les polítiques vigents: dret a l'habitatge, dret a la ciutat, dret a la llibertat de moviments de les persones immigrants, dret a la participació política i dret al lliure accés i producció de cultura. ${ }^{7}$

Situat al carrer Magadalenes 13-15, es tractava d'un edifici sencer, amb habitatges i centre social, que fou okupat el maig de $2005 .{ }^{8}$ Des del principi, comptà amb el suport dels veïns «legals», víctimes de l'assetjament immobiliari i de les intencions de construir un hotel en aquell local. El seu bon ús d'estratègies d'emmarcament positives davant els mitjans de comunicació i la seva disposició explícita a la negociació, ${ }^{9}$ l'enfrontaren a part del moviment okupa, però al mateix temps facilitaren la seva continuïtat malgrat trobar-se en ple centre de Barcelona. El primer intent de desallotjament, el 15 de febrer de 2010, fou frustrat gràcies a la concentració de centenars de veïns. L'1 d'abril de 2010, però, s'acabà executant el desallotjament posant fi a un procés de diàleg que les administracions no atengueren.

L'Espai Social Magdalenes esdevingué un projecte públic obert als moviments socials $i$ al teixit associatiu del barri. Aquest espai ha generat xarxes $i$ iniciatives culturals i polítiques des de les quals s'han articulat i s'articulen respostes i solucions a les problemàtiques i reptes socials que experimenta actualment el centre històric de Barcelona: la creixent gentrificació, l'assetjament immobiliari, la pressió turistificadora, l'èxode poblacional i d'activitats, i el debilitament de les xarxes socials existents i d'acollida de població nouvinguda.

Durant cinc anys l'es Magadalenes fou un espai de trobada d'associacions veïnals, moviments en defensa del dret a l'habitatge (V de Vivienda, Taller contra la Violència Immobiliària i Urbanística), moviments en defensa dels drets de les persones immigrants, així com d'iniciatives que promouen l'ús

7 Vegeu http://magdalenes.net/?q=ca/taxonomy/term/48.

8 Dins la història del moviment les successives okupacions de Miles de Viviendas des de 2003 (dos dies al Turó de la Peira, uns mesos al carrer Sardenya i quatre anys a la Barceloneta) ja marcaven aquesta tendència mitjançant la qual okupes activistes troben cases en un context d'alts preus del lloguer $\mathrm{i}$ fomenten l'okupació d'habitatges per gent amb necessitat.

9 Sobre estratègies d'emmarcament i oportunitats polítiques dels moviments socials, vegeu Máiz (1996). 
del programari lliure i aposten per un accés no restrictiu a la producció i distribució cultural. Finalment, cal destacar que l'es Magdalenes no va ser una iniciativa aillada d'aquesta transició de moviment per l'okupació a moviment per l'habitatge, sinó que s'emmarcà dins l'anomenada PHRP (Promoció d'Habitatge Realment Públic). La PHRP mantenia a inicis de 2008 quatre okupacions d'habitatges amb aquest nou enfocament al districte de Ciutat Vella. A més de l'es Magdalenes estaven okupats Avinyó 33, Amargós 6 i Tallers 44.

Amb plantejaments molt similars als de l'Es Magdalenes, s'okupà el 2007 al barri de Malasaña de Madrid, l'Espacio Polivalente Autogestionado Patio Maravillas. El Patio Maravillas esdevingué un espai central dels moviments socials madrilenys, gràcies a la seva identitat oberta i la seva arquitectura. El primer Patio se situà en un col•legi abandonat amb un gran pati al mig. La filosofia del Patio Maravillas fou la de defugir l'estereotip okupa i presentarse com un espai de participació social i cultural obert a tots els moviments socials, col-lectius i individus. La seva estratègia, davant el seu procés de desallotjament fou reunir el màxim de suports socials i dialogar amb l'Ajuntament de Madrid la possibilitat d'expropiació del local. En aquest projecte, el Patio Maravillas comptà amb el suport de la Federació Regional d'Associacions de Veïns de Madrid (FrAvM) i d'Ecologistes en Acció. Malgrat aquest suport, el Patio fou desallotjat d'aquest edifici del carrer Acuerdo a inicis de 2010. La mateixa nit del desallotjament, com a punt culminant a la manifestació de rebuig, s'okupà un altre espai al mateix barri -al carrer Pez- on continuaren les activitats d'aquest centre social (El País, 2 d'agost de 2010).

Després d'aquesta breu ressenya sobre els espais que situen les primeres confluències o transicions entre moviment per l'okupació i moviment per l'habitatge a Espanya, tornem a la història dels orígens del moviment per l'habitatge. La manifestació del 2 de juliol de 2006 sota la consigna de No tendrás una casa en la puta vida congregà milers de persones arreu de l'Estat. Les convocatòries del 30 de setembre i del 23 de desembre de 2006 seguiren en la mateixa línia. Després, una certa resposta per part de les institucions (Llei d'Habitatge a Catalunya i ajuts al lloguer de Zapatero) empetití les convocatòries de 2007 i 2008 . Però el moviment guanyà en extensió, descentralització i autoorganització.A part de $\mathrm{V}$ de Vivienda -nucli fundacional- sorgiren desenes de plataformes locals per l'Habitatge Digne, així com altres de temàtiques, com les Plataformes dels Afectats per la Violència Immobiliària (mobbing) o les PAH.També l'elaboració discursiva i les propostes concretes guanyaren en pes i solidesa.

L'evolució de la crisi de les hipoteques, la irrupció del 15-M i el repertori de protesta radical, solidari i democràtic, basat en aportar solucions a les 
persones afectades, seran les claus de la pervivència i el creixement d'un d'aquests col-lectius, les PAH. A Barcelona, la PAH neix el febrer de 2009 a iniciativa de $V$ de Vivienda. L'any 2013 ja hi havia 40 nuclis de les РAн a Catalunya i uns 130 a tot l'Estat espanyol. La generació d'eines d'empoderament de les persones afectades ha estat el secret del creixement d'aquest moviment associatiu que refusa l'assistencialisme i aposta per l'acció col·lectiva directa com a única sortida a la situació de les persones que estan en processos de desnonament.

El repertori d'acció col-lectiva de les PAH combina elements de negociació política amb les administracions i les entitats financeres, amb accions de pressió a entitats o persones, sobretot campanyes de boicot que afecten la imatge pública de les entitats o escraches a dirigents polítics. ${ }^{10}$

Les PAH també han utilitzat la via legal acudint als jutjats a defensar els hipotecats. I la via legislativa, amb la presentació d'una Iniciativa Legislativa Popular (ILP) per la dació en pagament. Aquesta ILP fou presentada amb més d'un milió i mig d'avals populars. La seva tramitació -acceptada in extremis per un canvi de posició dels dos grans partits polítics del Parlament espanyol- suposà per sí sola el major impacte de tipus operatiu que ha tingut un moviment social en els darrers 20 anys. En tot cas, la ILP fou rebutjada per la majoria absoluta del PP.

Les РAH han aturat 600 desnonaments en quatre anys, la qual cosa demostra la seva eficiència com a mecanisme de suport mutu i la seva habilitat negociadora, que contrasta amb la posició més clarament contestatària i anticapitalista del moviment per l'okupació. La composició de les PAH és, d'altra banda, més plural que la del moviment okupa, destacant la presència de persones immigrades i de classe popular, juntament amb persones de classe mitja. Pel que fa a l'edat, les PAH presenten també una gran varietat, mentre que l'entorn okupa té una majoria juvenil.

Els reptes organitzatius que presenta el moviment per l'habitatge són enormes. Segons una de les seves portaveus més conegudes «no donem abast per respondre a tothom» (entrevista a Ada Colau, 2013). ${ }^{11}$ A Catalunya el moviment ha crescut de forma més homogènia i organitzada que a la resta de l'Estat. Avui ja compta amb una trobada mensual de plataformes i una coordinadora. Cal tenir en compte que les PAH són un moviment de base, sense subvencions, autogenerat per persones afectades, amb mecanis-

10 L'escrache té el seu origen més recent en les pràctiques de desobediència civil no violenta activa del moviment argentí HIJOs, per denunciar els genocides de la Dictadura que havien estat indultats pel Govern de Menem (Gradel, 2011).

11 Disponible a http://www.vilaweb.tv/implicats-amb-ada-colau. 
mes d'autoformació col-lectiva. A Barcelona hi ha diferents reunions tots els vespres al carrer Enamorats, que s'ha quedat petit per acollir la demanda social. Accions per aturar desnonaments, per pressionar les entitats financeres i escraches formen part del seu repertori d'acció col-lectiva més disrusptiu, i les que més l'emparenten amb les formes de fer del moviment per l'okupació.

A les PAH, en tant que moviment que ja es pot considerar de masses (la darrera manifestació del 16 de febrer de 2013 aplegà centenars de milers de persones a les principals capitals de tot l'Estat), se'ls hi interpel-la molt més que al moviment d'okupació per qüestions de regeneració democràtica i per la necessitat de vincles amb les lluites en defensa dels serveis públics. Ara bé, des de les PAH es fan anàlisis del problema de l'habitatge molt similars als que l'okupació porta plantejant 30 anys, tot i que a diferència d'aquest, es presenten a més de l'anàlisi, tota una sèrie de propostes possibilistes o reformistes.

Així doncs, les PAH coincideixen amb el moviment okupa en la definició del marc d'injustícia. Espanya és el país d'Europa que més habitatges buits té. Per a les PAH, en referència als pisos buits en mans d'entitats financeres, caldria prioritzar-ne l'ús social sobre l'ús especulatiu. Les PAH aposten pel loguer social assequible, per un màxim del $30 \%$ dels ingressos familiars. En canvi, les entitats nacionalitzades pel Fondo de Restructuración Ordenada Bancaria (ғRов) com Bankia i Catalunya Caixa segueixen executant i acumulant pisos buits. La Sareb (Sociedad de Gestión de Activos Procedentes de la Restructuración Bancaria) o banc dolent, també té milers de pisos, que l'Estat està oferint a inversors estrangers per reactivar el cicle especulatiu. Les PAH demanen que aquests habitatges buits s'obrin al lloguer social. Davant de la situació d'emergència i la manca d'accions des de les polítiques públiques, les PAH donen suport a l'okupació d'immobles buits que pertanyen a les entitats financeres. I és aquí on l'okupació esdevé per a les PAH una acció legítima orientada a un fi, però no un fi en si mateix.

Finalment, una altra de les propostes de les PAH és la dació en pagament. Aquesta proposta és ja una realitat en molts casos gràcies a l'acció col-lectiva de les PaH.Ara bé, la dació en pagament negociada també provoca un desnonament voluntari a canvi de saldar el deute i aquesta població també ha de ser atesa, per la qual cosa no és una solució ni molt menys definitiva al problema (Colau i Alemany, 2013).

Per concloure, el salt definitiu a l'arena política institucional de la generació d'activistes que han animat moviments com el 15-M, les PAH i les marees en defensa de la sanitat i educació públiques es produí amb la generalització 
de candidatures ciutadanes municipalistes el maig de 2015. A Barcelona, la candidatura de confluència Barcelona en Comú seria encapçalada per la ex-portaveu de la PAH Ada Colau, mentre que a Madrid, la candidatura Abora Madrid, portaria a les seves llistes nombrosos activistes de la PAH. El mateix es pot dir de centenars de candidatures arreu d'Espanya.

\section{OKUPACIÓ I HABITATGE: SEMBLANCES I DIFERÈNCIES}

Alguns autors han estudiat a altres països europeus les diferències teòriques i pràctiques entre ambdós moviments. Per a Pruijt (2003) caldrà distingir en tot moment entre un moviment per l'habitatge que utilitza la pràctica de l'okupació com a tàctica, d'un moviment okupa pel qual "squatting itself is at the centre". Segons Katz i Mayer (1983) diverses variables estructurals del propi moviment ens poden presentar les clares diferències entre un $\mathbf{i}$ altre moviment, que poden però coincidir i col-laborar en moltes ocasions.

En primer lloc, el predomini d'una ideologia de caire autònom, que considera que la creació d'antagonismes amb el poder establert és la clau del canvi social, serà dominant en el moviment okupa, conferint-li un caire eminentment polític. D'altra banda, l'ús de l'okupació -més enllà de satisfer necessitats materials d'habitatge- per expressar i crear contracultura, és també un element distintiu d'un moviment okupa resistent a la cooptació. En tercer lloc, el moviment okupa s'organitza sempre de manera informal, mentre que el moviment per l'habitatge compta amb estructures més formalitzades i líders visibles. Finalment, en el clàssic debat de l'okupació com mitjà o com a finalitat en si mateixa, el moviment okupa reconeix aquesta ambivalència i situa la seva pràctica com un mitjà per dur a terme una transformació social més àmplia, i com a finalitat en si mateixa, per la crítica frontal a la propietat (pilar del capitalisme) i les possibilitats de crear illes d'autonomia social i vital en els centres socials i cases okupades.

Aquesta concepció de l'okupació com a moviment ha predominat a l'Estat espanyol en els darrers trenta anys. Ara bé, altres experiències com la Masoveria Urbana ${ }^{12}$ o el moviment per l'habitatge podrien obrir nous

12 Acords entre el propietari i els llogaters, mitjançant els quals el llogater fa millores en l'edifici a canvi de gaudir en períodes acordats per contracte de l'usdefruit de l'habitatge sense pagar una renda. Mataró fou la ciutat que comptà amb les primeres experiències mitjançant la tasca de l'associació Dret a Sostre (González, Peláez i Blas, 2002). La Llei del Dret de l'Habitatge de 2007, en el seu article 28, regulà la Masoveria de forma legal. Malgrat això no s'han fet molt extensius els contractes de Masoveria Urbana i es pot dir que només hi ha experiències aillades a diverses poblacions de Catalunya, algunes d'elles impulsades per la Cooperativa Integral Catalana (Ribugent i Solanas, 2013). 
escenaris a la negociació. Caldrà veure, però, si es resolen en institucionalització o cooptació, o si la dinàmica repressiva segueix sent la dominant, com fins ara. ${ }^{13}$

Dos models ideals de moviment en defensa de l'habitatge i de moviment okupa, podrien servir per distingir les estratègies negociadores de les de confrontació. També el tipus de relacions amb les institucions, els objectius, els models organitzatius o la pròpia concepció de l'okupació, com podem veure en el quadre següent.

\section{Quadre 1}

Diferències entre un moviment okupa i un moviment per l'habitatge (tipus ideals)

\begin{tabular}{lll}
\hline & Moviment okupa & Moviment prohabitatge \\
\hline Identitat & Forta, contracultural & Difusa, integrada \\
Relació amb institucions & Autonomia & Interlocució \\
Estratègia dominant & Confrontació & Disrupció/ negociació \\
Objectius & Anticapitalisme & Polítiques d'habitatge \\
Organització & Informal & Formalitzada \\
& Activistes & Activistes + afectats \\
Concepció de & Fi i mitjà & $\begin{array}{l}\text { Mitjà per accedir a un } \\
\text { habitatge }\end{array}$ \\
l'okupació & & Intergeneracional \\
\hline
\end{tabular}

Font: Elaboració pròpia, a partir de Pruijt (2003).

En la pràctica no trobarem cap moviment que s'ajusti a aquests tipus ideals, i de vegades trobarem situacions on un moviment prohabitatge presenta característiques similars a les d'un moviment okupa.Aquest fou el cas de Barcelona l'any 2006, on un fort moviment per un habitatge digne apare-

13 Els desallotjaments l'any 2014 de blocs de pisos de Salt i de Sabadell okupats per les respectives PAH locals, fan pensar que les administracions i els bancs segueixen tancats a la negociació, per la qual cosa la institucionalització o la cooptació semblen encara escenaris llunyans. 
gué sense estructures formalitzades, ni estratègies que facilitessin l'establiment d'àmplies aliances socials, la qual cosa, per alguns autors, l'abocà al fracàs (Aguilar y Fernández, 2010: 679).

En tot cas, les oportunitats polítiques que obria el Pacte Nacional de l'Habitatge a Catalunya o els ajuts al lloguer juvenil arreu de l'Estat coincidiren temporalment amb el sorgiment -a Catalunya i a Madrid- d'un moviment per un habitatge digne, diferent del moviment per l'okupació. Aquest fet demostrà que el de les okupacions no és -ni pretén ser- un moviment exclusivament orientat cap a aquest aspecte de les polítiques públiques. El moviment per l'habitatge va tenir una gran incidència en l'organització de grans manifestacions de joves en favor del dret a l'habitatge a les principals ciutats de l'Estat espanyol. Amb la crisi de 2008 el moviment s'ha estès a altres capes socials, com els afectats per les hipoteques. Aquesta qüestió posa en evidència que el moviment per l'okupació a l'Estat espanyol no és, fonamentalment, un moviment per l'habitatge. De fet, caldria caracteritzar-lo com un moviment on hi conviuen motivacions polítiques de ruptura amb el sistema capitalista amb estratègies alternatives de cerca d'habitatge i d'espais de convivència.

D'altra banda, la radicalitat de les propostes okupes i el seu atac a la propietat privada han dificultat l'emmarcament del seu discurs en els marcs mestres hegemònics. En un context de dominació simbòlica neoliberal, el moviment per l'okupació tindrà greus dificultats per emmarcar els seus discursos. Però en canvi, el fort suport social del moviment dels indignats del 15-M o de les PAH obren un nou cicle de lluites centrat en demandes bàsiques contra el model neoliberal de gestió de la crisi i en favor d'una democràcia real, amb autonomia dels mercats i lliure de les corrupteles i de la indiferència de la classe política.

Al llarg d'aquests 30 anys, certs discursos del moviment per l'okupació han penetrat en les polítiques públiques i han eixamplat el menú d'alternatives possibles. Per exemple, podem trobar aquesta circumstància en els casos en els que hi ha hagut negociació o a través de la generalització i extensió de polítiques juvenils afirmatives (relacionades amb el lleure o la formació en el temps lliure). En tot cas, a l'Estat espanyol, les administracions públiques han estat lluny de ser permeables a la influència de moviments socials de caràcter autogestionari. De fet, les darreres tendències mostren un increment de la pressió policial i judicial contra les okupacions. En concret, el Senat espanyol va aprovar el juliol de 2010 una nova reforma del Codi Penal que incrementà les penes per usurpació. Al mateix temps, i amb la pretensió oficial de facilitar el lloguer en temps de crisi, el 2010 entrà en 
vigor la Llei de mesures de foment i agilització del lloguer, que juntament amb les reformes de la Llei d'Enjudiciament Civil, aprovades el desembre de 2009, pretenen accelerar els desnonaments (Manrique, 2010).

Aquesta pressió legal i policial sobre les okupacions es produeix però en un context del seu creixement, en especial de les degudes a la pobresa. En concret, segons dades de l'Ajuntament de Barcelona, les okupacions havien crescut l'any 2009 en un 11,2 \% per situar-se en un total de 249 a la ciutat (Manrique, 2010). Aquestes xifres mostren que les condicions socials, econòmiques i urbanes que van fer sorgir el fenomen de les okupacions no sols no han remés, sinó que s'han accentuat.

En aquest context, les perspectives del moviment per l'okupació es presenten ambivalents. Per una banda, el moviment es troba en el centre d'una espiral de criminalització; però, per l'altra, la pràctica de les okupacions s'ha estès com mai a altres moviments socials i a persones amb problemes d'accés a l'habitatge. A més a més, el creixement d'un moviment d'ateneus, centres socials legals i noves forces polítiques emergents afins a les okupacions, garanteixen que el moviment no quedarà aillat. L'exemple més clar d'estratègies coincidents entre okupació i moviment per l'habitatge són les pròpies okupacions promogudes per la PAH. ${ }^{14}$ D'altra banda, altres okupacions vinculades al $15-\mathrm{M}$ desenvolupen projectes similars però desvinculats de la PAH.

Les PAH estan tenint forts impactes polítics i protagonisme en els darrers anys. Malgrat el seu perfil aparentment temàtic i moderat, estan aglutinant corrents polític partidaris de la regeneració democràtica i del canvi radical de sistema polític i econòmic. Les PAH afirmen sense embuts que cal fer fora del poder els responsables de la crisi i processar-los, ja que mentre hi ha impunitat no hi ha democràcia (entrevista a Ada Colau, 2013). Les PAH estan actuant com a moviment social generador de consciència col-lectiva $i$ han sabut situar un marc d'injustícia ${ }^{15}$ molt clar que ha connectat amb la majoria de la població. A partir d'aquest, les PAH han generat també un marc d'acció col-lectiva (Benford i Snow, 1994), és a dir, una disposició individual favorable a les accions promogudes contra els desnonaments per part d'un nombre significatiu de persones.

14 L'abril de 2013 hi havia vuit edificis a Catalunya okupats per l'Obra Social la PAH, tres a Sabadell, dos a Terrassa, un a Cerdanyola, un a Rubí i un a Girona. Les famílies pagaven un lloguer social i l'ingressaven davant notari en un compte per tal de demostrar la bona fe.

15 Sobre el concepte marc d'injustícia vegeu Gamson, Fireman i Rytina, 1982. Aquests autors defineixen els marcs com orientacions mentals que organitzen la percepció i la interpretació dels fenòmens socials. 
La demanda de noves formes de democràcia participativa i la vinculació a un dret de tipus materialista com l'habitatge, aterren al moviment per l'habitatge dins l'opinió pública de forma més evident que amb el moviment per l'okupació. Les seves reivindicacions de caire "reformista" el situen més proper als marcs simbòlics ${ }^{16}$ de la majoria dels ciutadans que no pas el radicalisme del moviment per l'okupació. L'aparició d'una nova fornada d'activistes urbans modernitza les vetustes formes del moviment veïnal. Tots aquests trets situen el moviment per l'habitatge com un moviment central en els cicles de mobilització i de lluita contra la gestió neoliberal de la crisi financera $\mathrm{i}$ per tant l'apropen -des de la pròpia pràctica i de forma paradoxal (o no)- als orígens anticapitalistes del propi moviment per l'okupació.

\section{CONCLUSIONS PRELIMINARS}

La primera conclusió quedarà com una qüestió oberta, pendent de posteriors estudis comparatius que comptin amb una major explotació de dades empíriques. Es tracta de veure si el moviment per l'habitatge que apareix a finals de la primera dècada del segle xxi constitueix una nova etapa de la història de les okupacions o bé s'ha d'abordar com un moviment separat i diferenciat del d'okupacions. En aquest article es demostra que el moviment d'okupacions o algunes de les seves components es troben en la gènesi del moviment per l'habitatge digne. El recorregut personal d'una de les seves portaveus més conegudes, Ada Colau, ens en dóna les pistes: Miles de Viviendas, l'es Magdalenes, $V$ de Vivienda i PAH.

També ha quedat clar que les diferències entre ambdós moviments són substantives en algunes dimensions analítiques: una identitat difusa i integrada del moviment per l'habitatge enfront d'una de contracultural més forta en el d'okupacions; una predisposició immediata a la negociació per part del moviment per l'habitatge i una estratègia més autònoma de les okupacions; uns objectius concrets centrats en les polítiques d'habitatge per part del primer i uns objectius més generals i que entronquen amb les tradicions polítiques més transformadores per part de l'okupació; una organització un tant més formalitzada i amb interlocutors coneguts i on també es pot distingir entre activistes i afectats, contrasten amb una organització informal, basa-

16 Seguint Bourdieu (1991), podem afirmar que la PAH ha consolidat una forma de veure la política molt diferent ideològicament a la dels partits polítics convencionals. L'acció directa disruptiva en defensa d'un interès material com l'habitatge és percebuda com a legítima per amplis sectors socials. 
da en el treball diari dels activistes -tot i que no és descartable cert lideratge carismàtic- en el món de les okupacions.

Finalment, tant moviment per l'habitatge com moviment okupa proposen una economia social i cooperativa que torni a posar al centre les necessitats de la població i no el fet de generar el màxim lucre. Es pot afirmar que -tot i que amb tàctiques i identitats diferents- la finalitat darrera d'ambdós moviments coincideix en què cal transformar radicalment el sistema, i més enllà de solucionar un problema de polítiques públiques d'habitatge, lligar la seva solució a un canvi més global del sistema econòmic i polític realment existent.

\section{REFERÈNCIES}

Aguilar, S. y A. Fernández (2010): «El movimiento por la vivienda digna en España o el porqué del fracaso de una protesta con amplia base social», Revista Internacional de Sociología, 68, pp. 679-704.

Alonso, S. (2014): "Votas pero no eliges": la democracia y la crisis de la deuda soberana en la Eurozona», Recerca, Revista de Pensament i Anàlisi, 15, pp. 21-53.

AsENs, J. (2004): «La represión al movimiento de las okupaciones: del aparato policial a los mass media» a ADELL, R. i M. MARTínez (coords.) (2004): ¿Dónde están las llaves? El movimiento okupa:prácticas y contextos sociales, Madrid, Los Libros de la Catarata, pp. 293-337.

BENFORD, R. i D. SNOw (1994): «Marcos de acción colectiva y campos de identidad en la construcción social de los movimientos», a Gusfield J.i E. Laraña (eds.) (1994): Los nuevosmovimientos sociales: de la ideología a la identidad, Madrid, cIs.

Bourdieu, P., (1991): La distinción, Madrid, Taurus.

CALLE, Á. (2004): «Okupaciones: un movimiento contra las desigualdades materiales y expresivas", a Tezanos F. (2004): Tendencias en desigualdad $y$ exclusión, Madrid, Sistema, pp. 270-305

CASTILlo, E. i R. GonzÁlez (1997): Com i perquè d'aquestes almorranes kabrejades. Anàlisi d'un moviment de protesta política. El moviment per l'okupació a Catalunya, treball d'investigació, UAB, inèdit.

Colau, A. i A. Alemany (2012): Vidas hipotecadas. De la burbuja immobialiria al derecho a la vivienda, Barcelona, Cuadrilátero de libros.

- (2013): ;Si se puede! Crónica de una pequeña gran victoria, Barcelona, Destino. 
GonzÁlez, R., A. Blas i L. PelàEz (2002): «Okupar, resistir y generar autonomía. Los impactos políticos del movimiento por la okupación» a IBARRA, P., S. MARTí i R. GoMÀ (coords.) (2002): Creadores de democracia radical. Movimientos sociales $y$ redes de políticas públicas, Barcelona, Icaria, pp. 187-218.

González, R. (2011): Xarxes Crítiques i Polítiques Públiques: els impactes del moviment per l'okupació a Catalunya i Madrid (1984-2009), UAB, tesi doctoral.

Gradel, S. (2011): «Política, memoria y justícia. Los "escraches" como acción política de resistència», Revista Electrónica del Instituto de Investigaciones Ambrosio L. Gioja, año v, número especial, pp. 289-298.

Gamson, W., B. Fireman i S. RYTina (1982): Encounters with Unjust Autbority. Chicago, Dorsey Press.

Gofman, E. (1974): Frame analysis. An Essay on the Organization of Experience, Boston, Northeastern University Press.

Herreros, T. (2004): «Moviments socials i cicles de protesta: el cicle de protesta del capitalisme global, 1994-2003», ponència al VIII Congreso Español de Sociología, Alacant, FEs.

KATZ, S. i M. MAYER (1983): «Gimme Shelter: Self-help Housing Struggles within and against the State in New York City and West Berlin», International Journal of Urban and Regional Research, 9 (1), pp. 15-45.

Kitschelt, H. (1996): «Political oportunity structures and political protest : anti-nuclear movements in four democracies», British Journal of Political Science, 16, pp. 55-85.

Máız, R. (1996): «Nación de Breogán: oportunidades políticas y estrategias enmarcadoras en el movimiento nacionalista gallego (1886-1986)», Revista de Estudios Políticos, 92, pp. 33-75.

MANRique, P. (2010): «Medidas penales contra las okupaciones», Diagonal, del 8 al 21 de juliol de 2010, pp. 22-23.

Martínez, M. (2002): Okupaciones de viviendas y centros sociales. Autogestión, contracultura y conflictos urbanos, Barcelona, Virus.

- (2004): «Del urbanismo a la autogestión: una historia posible del movimiento de okupación en España» a Adell, R. i M. MARTínez (coords.) (2004): ¿Dónde están las llaves? El movimiento okupa: prácticas y contextos sociales, Madrid, Los Libros de la Catarata, pp. 61-88.

- (2007): «El movimiento de okupaciones: contracultura urbana y dinámicas alter-globalización», a PRIETO, R. (coord.) (2007): «Jóvenes, globalización y movimientos altermundistas», Revista de Estudios de Juventud, 76, pp. 225-243. 
- (2010): «El movimiento de okupaciones: una larga e inquietante existencia», Viento Sur, 108, pp. 43-48.

MarTínez, M. i Á. García (2013): «A convergence of antineoliberalism movements in Spain: Squatting, Housing and M15 movements» a http://www. miguelangelmartinez.net/ImG/pdf/Athens_2013_housing squatting_15M_v3.pdf, consultat el 2 de juny de 2014.

McAdam, D. (1998): «Orígenes conceptuales, problemas actuales y direcciones futuras», a IBARRA, P. i B.Tejerina (eds.) (1998): Los movimientos sociales. Transformaciones políticas y cambio cultural, Madrid,Trotta.

MIRó, I. (2001): «Okupació: superant la criminalització. Impulsant de nou la crítica práctica de l'urbanisme capitalista", Contracorrent, 5, pp. 4-5.

Moreno,A., A. López i S. SALGAdo (coord.) (2012): La transición de los jóvenes a la vida adulta. Crisis económica y emancipación tardía, Barcelona, Obra Social "la Caixa", Colección Estudios Sociales, 34.

PASTOR, J. (2002): ¿Qué son los movimientos antiglobalización?, Madrid, RBA Libros.

Pissarelo, G. i J. Asens (2013): «La criminalización de la pah: cuando el que "escracha es el poder», Sin permiso, a http://www.sinpermiso.info/textos/ index.php?id=5831, consultat el 9 d'abril de 2013.

PrujJ, H. (2003): «Is the Institutionalization of Urban Movements Inevitable? A Comparison of the Opportunities for Sustained Squatting in New Cork City and Amsterdam», International Journal of Urban and Regional Research, 27, pp. 133-157.

- (2004): «Okupar en Europa», a Adell, R. i M. MarTínez (coords.) (2004): ¿Dónde están las llaves? El movimiento okupa: prácticas y contextos sociales, Madrid, Los Libros de la Catarata, pp. 35-60.

Ribugent, G. i P. Solanas (2013): «La masoveria del segle xXI» a http://www.vilaweb.cat/noticia/4151276/20131022/masoveria-segle-xxi.html, consultat el 5 de juny de 2014 .

Romero, J. (2010): «Construcción residencial y gobierno del territorio en España. De la burbuja especulativa a la recesión. Causas y consecuencias», Cuadernos Geográficos, 47, pp. 17-46.

TARROW, S. (1997): El poder en movimiento. Los movimientos sociales, la acción colectiva y la política, Madrid, Alianza Universidad.

Trilla, C. i J. López (2007): «8.4. Vivienda» a V. Navarro (dir.) Informe 2007. Observatorio social de España. El Estado del Bienestar en España y las CC. AA. Análisis de indicadores clavehttp://www.seg-social.es/prdi00/ groups/public/documents/binario/51940.pdf, consultat el 30 de maig de 2014, pp. 745-776. 
106 RECERCA - DOI: http://dx.doi.org/10.6035/Recerca.2015.17.5 - ISSN: 1130-6149 - pp. 85-106

\section{ENTREVISTES}

Ada Colau, Vilaweb tv, 22 de març de 2013. Disponible a: http://www.vilaweb.tv/implicats-amb-ada-colau (consultada abril 2013). 